\title{
TOURAINE, A. UN NUEVO PARADIGMA PARA COMPRENDER EL MUNDO DE HOY. ESPANHA, BARCELONA. PAIDÓS IBÉRICA, 2005.
}

\author{
Aline Cristina Santana Rossi \\ Universidade do Oeste Paulista - UNOESTE - Presidente Prudente-SP. E-mail: line.csantana@hotmail.com
}

Alain Touraine, professor de Filosofia e diretor de pesquisas da École dês Hautes Études em Sciences Sociales desde 1960, em seu livro "Un nuevo paradigma para comprender el mundo de hoy" afirma que durante muito tempo os pesquisadores sociais analisavam a realidade com base em estruturas políticas: o poder e o Estado, o rei, a república etc. Com a revolução industrial e permanência do modo capitalista de produção, tem início uma série de pesquisas e perspectivas com fundamentos em um paradigma econômico e social: classes sociais, burguesia, desigualdades etc.

Para Touraine (2005) atualmente com o triunfo da economia sobre a política, muitas categorias e conceitos sociais nos aparecem confusos, deixando de maximizar seu potencial de explicação por meio da interpretação da realidade partindo da experiência do cotidiano. Isso, por sua vez, nos leva à necessidade de um novo paradigma, visto que a dimensão cultural e suas articulações ganham na contemporaneidade tamanho peso e relevância que ficaria desconexo uma correlação imbricada tão somente pelo viés político e que negasse ou não levasse em consideração os desafios que as relações sociais enfrentam e projetam.

A ideia preponderante defendida no livro diz respeito à busca pelo entendimento e compreensão desse novo paradigma. $O$ autor argumenta que não estamos mais vivendo a época em que tudo se explicava em termos sociais, mas sim num período que convida a todos pensarem esse novo paradigma cuja presença e influência podem ser percebidas na vida coletiva e pessoal.

Es ya hora de saber dónde estamos y cuál es el discurso sobre el mundo y sobre nosotros mismos que nos los hace inteligibles. Comencemos pues por tomar conciencia de la ruptura que nos aleja rápidamente de un pasado todavía próximo, antes de tratar de definir la naturaleza de este cambio de paradigma. (TOURAINE, A. 2005, p. 16)

No trecho acima abordado, o autor deixa claro o que implica conhecer o novo paradigma que nos é apresentado. Isto é, em quais perspectivas e orientações devemos pensar e por que refletir sobre tais questões. É dizer: entender como o mundo nos é transmitido, como nós o vivemos, quais as intencionalidades que estruturam e moldam as propagandas e os discursos da realidade social. Tais reflexões nos impulsionam no sentido de perceber as mudanças que ocorreram e ainda estão em execução para que, em uma etapa posterior, possamos avançar na compreensão desse novo paradigma.

O autor traça o desenvolvimento deste livro aqui apresentado, em um encadeamento lógico de ideias com importantes e interessantes debates e reflexões. São analisados temas como o surgimento da democracia, o papel das guerras, o retorno do pensamento político, as sociedades europeia e americana e a realidade da situação econômica e social da América Latina. Tais apontamentos em muito ajudam na leitura de modo a percebermos como ocorreram as transformações necessárias que culminam em outro paradigma. A decomposição, fragmentação da sociedade é analisada, por exemplo, como uma das formas extremas da modernização, quando o vínculo entre o sistema e o ator é rompido, quando a significação de uma norma ou diretriz para o sistema não encontra correspondência ao sentido que tem para o autor. 
Touraine (2005) entende que a dissociação entre a economia e os trabalhadores, o sistema e o ator, constitui o ponto crucial da definição da crise atual. A globalização constringe, interfere e influi em todos os países, industrializados ou não, impulsionando-os a utilizarem de forma ótima seus recursos humanos, competências e, com isso, elevar a produção. A partir dessa discussão, a modernidade é debatida pelo autor analisando como seu entendimento é tido por diversos pesquisadores. Alguns chegam a afirmar seu desaparecimento, com a entrada do pós-modernismo; no entanto, tomar esse posicionamento significa afirmar o desaparecimento do princípio histórico central da definição de conjunto social. Essa postura intelectual possui consequências tão gerais e radicais que podem levar a uma desorganização teórica e prática aos que dela se opõem.

A debilidade de nossas sociedades pode ser explicada não somente pelo esgotamento de seus modelos de desenvolvimento tradicional. Junto a essa análise introduz-se também uma autonomia e dominação crescente do mundo da guerra e o triunfo do consumo sobre os projetos de desenvolvimento em longo prazo. Para o autor, estamos mergulhados numa teia de relações na qual queremos existir como indivíduos em meio às técnicas, regras, formas de produção, de poder e de autoridade, porém também como seres que somos em que buscamos a afirmação das identidades.

O livro nos brinda com ricas formulações sobre como perceber as mudanças que operam na mudança de paradigmas, nos convidando ao debate e à reflexão. A preocupação de Alain Touraine com a cautela e rigor teórico é inserida do início ao fim da leitura; as práticas sociais que orientamos são analisadas pelo autor a partir dos modos que vivemos a vida, sendo que todos os modos de pensar e agir irão cada vez mais nos mobilizar a mudança, ao pensamento e à requalificação de nossas atitudes. 